\title{
Understanding stakeholder influence: lessons from a controversial megaproject
}

\section{Lara Gonzalez-Porras*, Anna Heikkinen and Johanna Kujala}

\author{
Faculty of Management and Business, \\ Tampere University, \\ Kanslerinrinne 1, 33014, Finland \\ Email: lara.gonzalezporras@tuni.fi \\ Email: anna.l.heikkinen@tuni.fi \\ Email: johanna.kujala@tuni.fi \\ *Corresponding author
}

\begin{abstract}
This study aims to extend the understanding of stakeholder influence in megaprojects by examining a controversial pulp mill project in Uruguay. The theoretical framework is based on stakeholder theory, focusing on stakeholder influences in international megaprojects. The research data comprise 96 newspaper articles from 2005 to 2009 , and qualitative content analysis is used in the empirical analysis. The findings present the main events of the megaproject and how the stakeholder-firm and inter-stakeholder influences emerged and evolved during the project. This research contributes to the existing knowledge of stakeholder influence in megaprojects by showing that stakeholder influences are interdependent and non-exclusive and that stakeholder influence evolves over time. Moreover, the study examines inter-stakeholder influence in addition to stakeholder-firm influence and extends the stakeholder-firm classification, contributing to the literature on secondary stakeholder influence. The managerial implications emphasise the importance of understanding how stakeholders can be influenced by or, alternatively, exert influence in megaprojects.
\end{abstract}

Keywords: stakeholder theory; stakeholder relationships; influence; megaprojects; conflict; case study; qualitative study; newspaper articles.

Reference to this paper should be made as follows: Gonzalez-Porras, L., Heikkinen, A. and Kujala, J. (2021) 'Understanding stakeholder influence: lessons from a controversial megaproject', Int. J. Human Resources Development and Management, Vol. 21, Nos. 2/3, pp.191-213.

Biographical notes: Lara Gonzalez-Porras has received her Master's in Business Competence from University of Tampere, Finland. Currently, she is a Doctoral Researcher at the Tampere University Faculty of Management and Business. Her research focuses on stakeholder theory. She is interested in stakeholder engagement, corporate-community relationships, stakeholder influence, sustainability and business ethics.

Anna Heikkinen is a Senior Lecturer of Management and Organisations at the Tampere University, Faculty of Management and Business. She is the Academic Director of Responsible Business Master's degree Program. Her research is primarily in the areas of stakeholder theory, urban sustainability and corporate sustainability, examining the relationships between business 
organisations and the society. Her work has been published in edited volumes and international journals, such as Journal of Business Ethics, Business Communication Quarterly, and International Journal of Knowledge Management Studies.

Johanna Kujala is a Professor of Management and Organisations, the Vice Dean for research, and Director of the RESPMAN Responsible Management Research Group at the Tampere University, Faculty of Management and Business. She has published over 50 scholarly articles in international peer-reviewed journals and volumes, and currently serves as a member of the review boards of the Journal of Business Ethics and the Business Ethics: A European Review. She has acted as a Visiting Scholar in the University of Virginia and the University of Chieti and Pescara. She is the PI of the B2N Business to Nature research project funded by the Academy of Finland, and a WP Leader in the CICAT2025 Circular Economy Catalysts research project funded by the Finnish Strategic Research Council. Her current research interests focus on circular economy, stakeholder engagement and value-creation, and corporate responsibility and sustainability.

This paper is a revised and expanded version of a paper entitled 'Case Botnia in Uruguay: stakeholder influence strategies' presented at International Conference on Management Cases ICMC2017 at BIMTECH Birla Institute of Management Technology, 30 November to 1 December 2017.

\section{Introduction}

The purpose of the current study is to extend the understanding of stakeholder influences in megaprojects. Megaprojects are "large-scale, complex ventures that typically cost US\$1 billion or more, take many years to develop and build, involve multiple public and private stakeholders, are transformational, and impact millions of people" [Flyvbjerg, (2014), p.6]. Megaprojects are inherently complex and uncertain as they involve various public and private stakeholders in the host country, presenting a diversity of stakes (Aaltonen et al., 2010; Flyvbjerg, 2014).

This study focuses on a megaproject in which a Finnish forest industry company, Metsä-Botnia (hereafter Botnia), invested in a pulp mill project in Uruguay. This project fulfils the megaproject criteria as the cost of the investment was approximately USD 1.1 billion, the construction works took place from 2005 to 2007, the project and the ensuing conflict involved numerous and diverse stakeholders, and the pulp mill was expected to increase the Uruguayan GDB by $1,6 \%$ and to create 8,000 jobs (Aaltonen and Kujala, 2010; Kujala et al., 2012).

The stakeholders surrounding and being affected by a megaproject can influence the firm and the success of the project both positively and negatively (Hendry, 2005; Kolk and Fortanier, 2013). Stakeholder research has extensively examined stakeholder management and dyadic firm-stakeholder relationships from the perspective of the focal firm (Laplume et al., 2008). Similarly, research on megaprojects has mainly examined stakeholders from the perspective of how the firm can manage its stakeholders (Di Maddaloni and Davis, 2017; Mok et al., 2015; Yang et al., 2011). However, to build working relationships with stakeholders and to avoid conflicts, the investing firm is required to understand the stakeholders' interests and anticipate their actions and 
influence methods (Aaltonen, 2013). Consequently, there is a need for an in-depth understanding of how stakeholders influence firms (de Bakker and den Hond, 2008a).

Research on stakeholder influence has explicated, on the one hand, how firms respond to stakeholder influences (de Bakker and den Hond, 2008b; Pacheco and Dean, 2015) and, on the other hand, how stakeholders may gain and hold influence over firms (de Bakker and den Hond, 2008b; Eskerod et al., 2015; Frooman, 1999; Hendry, 2005; Zietsma and Winn, 2008). While Di Maddaloni and Davis (2017) have identified secondary stakeholder influences and local opposition as one of the key challenges in megaprojects, the literature is lacking in empirical studies focusing on stakeholder-firm and inter-stakeholder influences, especially in the context of international megaprojects (Mok et al., 2015).

The research question of this study is: How does stakeholder influence emerge and evolve in megaprojects? We are interested in both stakeholder-firm and inter-stakeholder influences. Analysing both perspectives is important to more thoroughly understand the stakeholder relationships and influence surrounding and affecting megaprojects. Empirically, we analyse stakeholder influence related to the megaproject of Botnia, a Finnish forest industry company in Uruguay. The project started in 2005 when the company decided to invest in constructing a pulp mill in the Uruguayan city of Fray Bentos, by the River Uruguay, which is the frontier between Uruguay and Argentina. Prior to 2005, the company had commenced research on pulp production and disseminated information regarding pulp mills in Uruguay. Soon, the Argentinean Government and the local community voiced their opposition toward the project because they feared there would be negative environmental consequences for the River Uruguay. This situation evolved into an international conflict, involving several stakeholders that reacted in diverse ways. Thus, this project provides a fruitful case for examining stakeholder influence in megaprojects.

The project under scrutiny in our study has received substantial consideration in previous research. For example, research has examined stakeholder salience in project management (e.g., Aaltonen and Kujala, 2010); relationships between multinational corporations, host governments, and NGOs (Skippari and Pajunen, 2010); stakeholder relationships and dialogue (Kujala et al., 2012; Laasonen, 2010; Lehtimäki and Kujala, 2017), corporate responsibility communication (Kujala et al., 2009; Lehtimäki et al., 2011); and legitimacy in corporate social responsibility (Joutsenvirta and Vaara, 2009). Lehtimäki and Kujala (2017) presented a detailed analysis of previous research on the project and concluded that it should be seen as a dynamic process where stakeholder influences change over time.

The research contributes to the existing knowledge of stakeholder influence in megaprojects in at least three ways. First, the study shows that stakeholder influences are interdependent and non-exclusive, and that stakeholder influence evolves over time through the main events of a megaproject. Second, we argue that in addition to stakeholder-firm influence we need to study inter-stakeholder influence to fully understand how stakeholder influence emerges and evolves in megaprojects. By extending the stakeholder-firm framework (den Hond and de Bakker, 2007) to inter-stakeholder influence, we show that stakeholder influence consists of the multiple and simultaneous interests that the focal firm must consider (Rowley, 1997; Zietsma and Winn, 2008). Third, by analysing the inter-stakeholder influence, we contribute to the literature on secondary stakeholders and the ways their influence is understood in megaprojects (Di Maddaloni and Davis, 2017). 
The rest of the article is organised as follows. First, previous literature on stakeholder influence in megaprojects is presented. After that, the data and research methods are explained. Then, the results of the study are presented by identifying the main events of the megaproject and the stakeholders' influence in relation to these events. The findings reveal both stakeholder-firm and inter-stakeholder influences in the project. The study concludes with the theoretical contributions and managerial implications.

\section{Stakeholder influence in megaprojects}

The seminal definition by Freeman $(1984$, p.46) identifies a stakeholder as 'any group or individual who can affect or is affected by the achievement of the firm's objectives'. According to Clarkson (1995), stakeholders can be classified into primary and secondary stakeholders. Primary stakeholders are needed for the organisations' survival. Secondary stakeholders have an interest in the organisations' operations but are not essential for it to survive (Clarkson, 1995).

To provide a framework for stakeholder management, the literature has extensively discussed the dyadic firm-stakeholder relationship (Bunn et al., 2002). More recently, stakeholder research has shifted toward a stakeholder orientation, where the focus has moved from focal firm orientation to stakeholder behaviour and inter-stakeholder relationships as stakeholders relate both to the firm and to other stakeholder groups (Bunn et al., 2002; Lehtimäki and Kujala, 2017; Neville and Menguc, 2006; Zietsma and Winn, 2008), thereby creating a complex and interdependent network of stakeholder relationships (Rowley, 1997; Rowley and Moldoveanu, 2003). Consequently, the firm is required to respond to 'multiple interactions from the entire stakeholder set' instead of responding to each stakeholder individually [Rowley, (1997), p.890].

Pacheco and Dean (2015) presented that the reactions of firms to stakeholder influence depend on their market situation and the reactions of their competitors toward the same pressure. Firms' responses to stakeholder influence typically include various strategies for managing stakeholder expectations, such as creating issue management departments, establishing business roundtables, writing codes of conduct, setting up certification schemes, and reporting stakeholder management activities (de Bakker and den Hond, 2008b).

In megaprojects, stakeholders can utilise different tactics and strategies to influence the decision-making processes and further the various interests related to the project. Based on resource dependence theory, Frooman (1999) identified the following stakeholder influence strategies that can affect the organisation: direct and indirect usage strategies as well as direct and indirect withholding strategies. Later, Frooman and Murrell (2005) added that stakeholders may seek to affect an organisation's behaviour by using manipulation strategies, such as coercion and compromise, as well as direct and indirect pathway strategies, referring to whether stakeholder groups or allies exert influence on the organisation. Moreover, Hendry (2005) argued that Frooman's (1999) original framework is too parsimonious as it does not recognise the simultaneous use of different influence strategies nor explain the reasons behind the strategy choice or cover the possibility of coalitions with non-powerful allies. Instead, Hendry (2005) identified seven stakeholder influence strategies, including allying with other stakeholders, multi-stakeholder dialogues, letter-writing campaigns, blockades, boycotts, litigation, and lobbying legislators. 
den Hond and de Bakker (2007) presented a classification of tactics that stakeholders may use to influence corporate social change activities. The classification is based on the intended outcome of the use of the tactic (logic of damage and gain) and on the extent to which the success of the tactic relies on the participation of a large number of individuals (logic of numbers). The classification is presented in Table 1.

The outcomes are categorised as material damage or gain and as symbolic damage or gain. Material forms focus on bringing about change in firms' technologies, operations, and resources, while symbolic forms seek to influence dominant meanings, understandings, and public opinion (Morrill et al., 2003). For example, material damage can occur when the activists slow down or prevent the company's operations, and symbolic damage can refer to a situation where the company's reputation is critiqued in the media. While symbolic damage does not always include the aim to cause material damage, it contains the threat of doing so (den Hond and de Bakker, 2007). Material gain can occur when stakeholders organise to support a firm by buying its products (buycott) and symbolic gain when the firm's reputation is reinforced by stakeholders. The logic of numbers refers to participatory actions, which can be understood as mass participation or elite participation. Elite participation can be used when a small number of stakeholders have high-quality resources they can utilise to influence the firm (den Hond and de Bakker, 2007). Den Hond and de Bakker (2007) argue that the choice of tactic is motivated by ideological differences among activist groups.

Table 1 Classification of stakeholder influence

\begin{tabular}{lcc}
\hline Intended outcome & $\begin{array}{c}\text { Dependence on participatory } \\
\text { forms of actions is high (mass } \\
\text { participation) }\end{array}$ & $\begin{array}{c}\text { Dependence on participatory } \\
\text { forms of actions is low (elite } \\
\text { participation) }\end{array}$ \\
\hline Material damage & Boycott & $\begin{array}{c}\text { Blocking of gates, sabotage, } \\
\text { occupation of premises, Internet } \\
\text { activism (hacktivism), lawsuits }\end{array}$ \\
Material gain & Buycott & Cooperation \\
Symbolic damage & $\begin{array}{c}\text { Writing letters/e-mails, petitions, } \\
\text { marches, rallies }\end{array}$ & $\begin{array}{c}\text { Shareholder activism, street } \\
\text { theatre, negative publicity, } \\
\text { research }\end{array}$ \\
Symbolic gain & Voluntary action & Positive publicity, cooperation \\
\hline
\end{tabular}

Source: den Hond and de Bakker (2007)

The presented classification has been utilised to some extent in empirical research. For example, de Bakker and den Hond (2008b) discussed activist groups' tactics to influence corporate policy and described corporate policy responses to these tactics, while King (2008) emphasised the importance of a shared goal, a shared identity, the mobilisation of structures, and the establishment of interpersonal relations. More recently, as a result of a study on stakeholder influence in the mining sector, Viveros (2017) suggested that stakeholders use five principal mechanisms to influence companies, including demands, communication, counselling, control, and engagement, and concluded that these mechanisms can be used simultaneously and actively or passively.

In megaprojects, one of the main challenges for the focal firm is the identification and balancing of the diverse stakeholders and their interests (Di Maddaloni and Davis, 2017; Mok et al., 2015). According to Aaltonen et al. (2010), megaprojects involve many stakeholders with various interests, who can affect the projects by using misinformation 
or by creating unexpected events. Stakeholders can also influence the success of the project in a positive way as they can mediate and affect the legitimacy of the project in the society (Aaltonen, 2013; Moffat and Zhang, 2014). Additionally, stakeholders may provide market knowledge to the firm, facilitating the adaptation of the project within the local environment and setting (Aaltonen et al., 2010). Di Maddaloni and Davis (2017) reviewed the literature on local community stakeholder influences in megaprojects and concluded that research has largely focused on those stakeholders who control the project resources. Di Maddaloni and Davis (2017) suggested that megaprojects may benefit from considering the local community's opinions, especially during the initiation and monitoring phases.

In summary, research on stakeholder influence in megaprojects has concluded that further empirical research is needed on stakeholder influence, especially on inter-stakeholder relationships (Eskerod et al., 2015; Mok et al., 2015) and secondary stakeholder influences (Di Maddaloni and Davis, 2017).

\section{Data collection and analysis}

The research data consist of newspaper articles on the Botnia project that were collected from the Argentinean newspaper El Clarín. The original data consist of 509 articles collected from 2005 to 2009. To reduce the data for analysis, we first used previous research to identify the key stakeholders influencing the project (Aaltonen and Kujala, 2010; Heikkinen et al., 2013; Kujala et al., 2012; Lehtimäki and Kujala, 2017). The following four stakeholders exerting various kinds of influence during the project were identified: the Government of Uruguay, the citizens of Fray Bentos, the Government of Argentina, and the Argentinean Citizens Environmental Assembly of Gualeguaychú (hereafter CEAG). After having identified the key stakeholders, we counted how frequently each of these stakeholders were cited in the articles. Then, we selected those articles where the relevant stakeholders were mentioned most frequently each month to be included in the final sample. Consequently, the final sample consisted of 96 newspaper articles from 2005 to 2009. Table 2 shows the number of articles in the original dataset and the final sample for each year. The final sample and the publication dates are presented in Appendix. In the findings, the articles are referred to using the publication date from Appendix, for example, 29/04/2005 refers to the first article that was published 29 April 2005. The original Spanish quotations were translated into English by the first author.

Table 2 Comparison between the original data and the final sample

\begin{tabular}{lcc}
\hline Year & Original dataset $(N)$ & Final sample $(n)$ \\
\hline 2005 & 35 & 11 \\
2006 & 156 & 23 \\
2007 & 170 & 26 \\
2008 & 80 & 18 \\
2009 & 68 & 18 \\
Total & 509 & 96 \\
\hline
\end{tabular}

Source: Compiled by the authors 
Qualitative content analysis was chosen as the method for data analysis because it is a particularly suitable approach for analysing documents and texts (Elo and Kyngäs, 2008). The purpose of qualitative content analysis is to reduce and condense the amount of initial information through coding so that only the most significant concepts remain, allowing the researcher to draw conclusions on the phenomenon being studied (Elo and Kyngäs, 2008). The current study utilised a deductive conventional content analysis (Hsieh and Shannon, 2005), which is based on previous theory and which moves from general information to more specific knowledge (Elo and Kyngäs, 2008). A deductive approach is appropriate when testing and applying previous frameworks to new data and situations (Elo and Kyngäs, 2008).

The data analysis process proceeded as follows. First, we focused on identifying the main events of the project. After that, we analysed what kind of stakeholder influences emerged and were utilised in each main event. We utilised the classification of stakeholder influence (den Hond and de Bakker, 2007) to analyse the stakeholder influences. Finally, we explicated on how stakeholder-firm and inter-stakeholder influences evolved during the project.

\section{Stakeholder influence in the megaproject}

As a result of our analysis, we identified four main events in the megaproject under scrutiny. These events are naturally overlapping to some extent, but for the purpose of clarity we treat them as separate as each consists of a clear and identifiable set of interrelated actions. The first main event includes the investment decision and the emergence of the conflict. The second event narrates the escalation of the conflict. The third event focuses on the increasing involvement of external stakeholders in the dispute. Finally, the last main event involves the solution-seeking process.

\subsection{Emergence of the conflict}

In March 2005, the Finnish forest industry company Botnia officially announced the decision to construct a pulp mill in the Uruguayan city of Fray Bentos, which is located near the River Uruguay, the border river between Uruguay and Argentina. The decision was made after receiving the Uruguayan Government's authorisation of the project in February 2005. The decision was heavily argued for by the Uruguayan Government because of the economic advantages the pulp mill would bring to the country. However, the Argentinean Government opposed the project, fearing negative impacts on the environment and the local tourism. As a result, demonstrations and roadblocks impeding access to the main bridges connecting the countries were organised in Argentina in April 2005 when Botnia started the construction of the pulp mill. The CEAG and the citizens of Fray Bentos participated in these demonstrations.

In May 2005, Argentina claimed that Uruguay had not consulted its government nor requested permission to build the pulp mill close to the River Uruguay, which would have been required because of a bilateral agreement signed by Argentina and Uruguay on the water usage of the River Uruguay. Consequently, Argentina requested the relocation of the mill. As a response, the Government of Uruguay claimed that the project fulfilled all the legal safety requirements and emphasised its government's support for the project. Table 3 summarises the stakeholder influence tactics utilised during the first main event 
of the megaproject by the key stakeholders, being the Uruguayan Government (UG), the citizens of Fray Bentos (CFB), the Argentinean Government (AG), and the Argentinean Citizens Environmental Assembly of Gualeguaychú (hereafter CEAG)

During the emergence of the conflict, the influence tactics used by the Governments of Argentina and Uruguay can be classified as elite participation as they involved a limited number of influential stakeholders - that is, the government officials. The Government of Uruguay influenced the project by providing material (project authorisation) and symbolic support for the company. The influence of the Argentinean Government can be categorised as symbolic damage as they verbally accused the Uruguayan Government and Botnia. The CEAG and the citizens of Fray Bentos used mass participation to organise joint demonstrations against the company and the Uruguayan Government. This influence was symbolic as the aim was to influence the public regarding their attitudes toward the project. As the roadblocks were organised by a limited number of CEAG members, we have classified them as elite participation. During the first main event, mass participation tactics with the intention of material damage or gain were not utilised.

Table 3 Stakeholder influence tactics utilised during the emergence of the conflict

\begin{tabular}{|c|c|c|}
\hline Intended outcome & Mass participation & Elite participation \\
\hline Material damage & (Not utilised) & $\begin{array}{l}\text { - CEAG: Roadblocks on bridges } \\
\text { against Botnia and the } \\
\text { Uruguayan Government }\end{array}$ \\
\hline Material gain & (Not utilised) & $\begin{array}{l}\text { - UG: Project authorisation to } \\
\text { Botnia }\end{array}$ \\
\hline Symbolic damage & $\begin{array}{l}\text { - CEAG: Demonstrations against } \\
\text { Botnia and the Uruguayan } \\
\text { Government }\end{array}$ & $\begin{array}{l}\text { - AG: Verbal accusations against } \\
\text { the Uruguayan Government and } \\
\text { Botnia }\end{array}$ \\
\hline- & $\begin{array}{l}\text { - CFB: Demonstrations against } \\
\text { Botnia and the Uruguayan } \\
\text { Government }\end{array}$ & $\begin{array}{l}\text { - UG: Verbal accusations against } \\
\text { the Argentinean Government }\end{array}$ \\
\hline Symbolic gain & $\begin{array}{l}\text { - CFB: Supporting CEAG in the } \\
\text { demonstrations against Botnia } \\
\text { and the Uruguayan Government }\end{array}$ & - UG: Supporting Botnia in project \\
\hline
\end{tabular}

Source: Compiled by the authors

\subsection{Escalation of the conflict}

In July 2005, the World Bank's International Financial Corporation (IFC) announced the preparation of a cumulative impact study (CIS) on the project, and Argentina declared that funding should be cancelled until the CIS was finalised.

In August 2005, the conflict became a 'national issue' and a 'problem of the Republic' in Argentina, with the Argentinean Government supporting the CEAG's actions and coordinating 'actions with municipalities, regional governments, and civil society' (23/08/2005). In September 2005, the CEAG organised a massive protest that included roadblocks against Botnia. As a result, the Uruguayan Government decided to 'coordinate actions with Botnia to overcome the demands and complaints from Argentina' (19/10/2005). In November 2005, the Argentina Custom House paralysed key exports to Botnia and, during December 2005, the CEAG continued the roadblocks, 
defined as a 'tourist boycott' and a 'peaceful protest' to promote a 'healthy life and a clean environment' (30/12/2005). The CEAG claimed that the roadblocks were a consequence of the 'project by Botnia and the uncompromising position of the Uruguayan Government' (30/12/2005).

In January 2006, while the CEAG intensified the roadblocks against Uruguay, the Uruguayan and Argentinean Governments agreed on organising meetings to settle the dispute. In Uruguay, the government showed its concern about the roadblocks and its support for the project, and Argentina requested the suspension of the project. During early 2006, the citizens of Fray Bentos changed from opposing the project to showing acceptance and support as a response to the dispute becoming a national issue between Argentina and Uruguay and as a method to show their trust in the Uruguayan Government.

In March 2006, the Argentinean and Uruguayan Governments requested Botnia to suspend the construction project for 90 days as a 'gesture to advance in the negotiations' to solve the dispute (16/03/2006). Both governments planned to create a joint committee to assess the consequences of the project on the River Uruguay. In addition, Argentina promised that the roadblocks on the bridges would be removed. However, Botnia only suspended the construction for 10 days, leading to the cessation of the negotiations between Uruguay and Argentina, so the roadblocks continued on the border bridges. Consequently, Uruguay suspended the bilateral negotiations with Argentina and cancelled its participation in the bilateral joint committee designed to evaluate the consequences of the project on the river. The influence tactics utilised by the key stakeholders during the escalation of the conflict are presented in Table 4.

Table 4 Stakeholder influence tactics utilised during the escalation of the conflict

\begin{tabular}{|c|c|c|}
\hline Intended outcome & Mass participation & Elite participation \\
\hline Material damage & (Not utilised) & $\begin{array}{l}\text { - AG: Involvement of World Bank } \\
\text { to cancel funding to Botnia, } \\
\text { paralysed exports to Botnia } \\
\text { - CEAG: Roadblocks against } \\
\text { Botnia and the Uruguayan } \\
\text { Government }\end{array}$ \\
\hline Material gain & (Not utilised) & - (Not utilised) \\
\hline Symbolic damage & $\begin{array}{l}\text { - CEAG: Demonstrations against } \\
\text { Botnia and the Uruguayan } \\
\text { Government } \\
\text { - CFB: Opposing CEAG and its } \\
\text { roadblocks and demonstrations } \\
\text { by supporting Botnia }\end{array}$ & $\begin{array}{l}\text { - AG: Verbal accusations, support } \\
\text { to CEAG in their activities } \\
\text { against Botnia } \\
\text { - UG: Verbal accusations and } \\
\text { suspension of negotiations with } \\
\text { Argentinean Government }\end{array}$ \\
\hline Symbolic gain & $\begin{array}{l}\text { - CFB: Supporting Botnia by } \\
\text { opposing CEAG's activities }\end{array}$ & $\begin{array}{l}\text { - AG: Support CEAG in } \\
\text { roadblocks and demonstrations, } \\
\text { meetings with Uruguayan } \\
\text { Government } \\
\text { - UG: Support Botnia, meetings } \\
\text { with Argentinean Government }\end{array}$ \\
\hline
\end{tabular}


During the escalation of the conflict, stakeholders started to influence other stakeholders in addition to exerting influence on the project. Both governments continued to use tactics requiring elite participation. The Argentinean Government sought to influence Botnia directly by paralysing exports and indirectly by appealing to the World Bank and collaborating with the CEAG. The Uruguayan Government exerted symbolic damage on the Argentinean Government with the aim of influencing the decisions made by the government. Mass participation tactics were used by the CEAG, who continued to protest against the project, and by the citizens of Fray Bentos. During this event, the citizens of Fray Bentos started to support the project, and thus, the symbolic damage of their protests was targeted to the CEAG.

\subsection{Involvement of external stakeholders}

The dispute evolved into a politicised and mediatised conflict between Argentina and Uruguay. In May 2006, the Government of Argentina demanded the relocation of the pulp mill and decided to appeal to The Hague International Court of Justice (The Hague ICJ), alleging that the Uruguayan Government had violated the bilateral agreement concerning the use of the River Uruguay. Soon, Uruguay responded to the allegations of the Argentinean Government by claiming that the initial negotiations with Argentina had progressed without opposition from the Argentinean side. At the same time, Uruguay protested in the Organization of American States (OAS) about the roadblocks, claiming that those actions were damaging the tourism sector and the economy of the country. In July 2006, Uruguay presented a plaint in Mercosur, stating that the roadblocks represented a violation of the Mercosur Agreement, which permits free circulation and movement in Mercosur countries. Uruguay particularly criticised the passivity of Argentina regarding the roadblocks.

In July 2006, The Hague ICJ also denied the Argentinean request to temporarily cancel the project and rejected the Uruguayan demand to ban the roadblocks. In October 2006, the IFC and the Multilateral Investment Guarantee Agency (MIGA) completed the final CIS, adjudging that the pulp mill was operating in conformance with the required environmental standards and recognising its economic contributions for Uruguay. Consequently, the World Bank accepted to approve a loan to Botnia, and the MIGA authorised insurance for the project. However, the Argentinean Government did not acknowledge the conclusions of the CIS, and the roadblocks on the border bridges continued.

During this heated stage of the conflict, the bilateral relations between Argentina and Uruguay broke off. The roadblocks became a symbol for the CEAG's protests against the project and also for the passivity of and lack of actions by the Argentinean Government, which seemed to be 'deaf and mute' (17/10/2006). Table 5 summarises the stakeholder influence tactics used in this main event.

This main event revolved around the governments involving external stakeholders in the dispute. These actions can be classified as material and symbolic damage used mainly to directly influence the other stakeholders and, thus, indirectly the project. The involvement of external stakeholders was conducted by making official complaints to The Hague ICJ, the OAS, and Mercosur. These tactics can be classified as elite participation with the intended aim of inflicting material consequences. Notably, during this event, influence tactics intended to produce material or symbolic gain were not utilised as the Argentinean Government no longer supported the CEAG roadblocks. The 
CEAG continued to exert material and symbolic damage through roadblocks and demonstrations. In contrast to the previous events, the CEAG now also opposed Argentina in addition to opposing Uruguay and Botnia. The citizens of Fray Bentos did not influence the project or other stakeholders during this event.

Table 5 Stakeholder influence tactics utilised during the involvement of external stakeholders

\begin{tabular}{|c|c|c|}
\hline Intended outcome & Mass participation & Elite participation \\
\hline Material damage & (Not utilised) & $\begin{array}{l}\text { - CEAG: Roadblocks against Botnia, } \\
\text { the Uruguayan Government, and the } \\
\text { Argentinean Government } \\
\text { - UG: Plaints in the OAS and Mercosur } \\
\text { against Argentina and roadblocks } \\
\text { - AG: Appeal to The Hague ICJ } \\
\text { concerning the bilateral agreement }\end{array}$ \\
\hline Material gain & (Not utilised) & (Not utilised) \\
\hline Symbolic damage & $\begin{array}{l}\text { - CEAG: Demonstrations } \\
\text { against Botnia, the } \\
\text { Uruguayan Government, } \\
\text { and the Argentinean } \\
\text { Government }\end{array}$ & $\begin{array}{l}\text { - UG: Verbal accusations against the } \\
\text { Argentinean Government } \\
\text { - AG: Verbal accusations against the } \\
\text { Uruguayan Government, opposing of } \\
\text { the roadblocks }\end{array}$ \\
\hline Symbolic gain & (Not utilised) & (Not utilised) \\
\hline
\end{tabular}

Source: Compiled by the authors

\subsection{Solution seeking}

In November 2006, Argentina requested the King of Spain to act as an intermediary mediating in the conflict between both countries, but the results were unsuccessful. The dispute continued, and Uruguay demonstrated its support for Botnia by building the ONTUR harbour in Nueva Palmira in August 2007 to enable Botnia's pulp deliveries. In October 2007, both countries agreed that the solution to the dispute lay in The Hague's resolution, as diplomacy seemed unsuccessful because of irreconcilable positions. Argentina and Uruguay increased their diplomatic efforts to solve the conflict through meetings, discussing the creation of a joint committee for monitoring the impact of the project on the environment and the likelihood of suspending the roadblocks.

The pulp mill started its operations in Fray Bentos at the end of 2007. As a result, both the Uruguayan Government and the CEAG blocked all the border bridges in November 2007. This was a step backwards in the negotiations between the two countries. The CEAG intensified the roadblocks and threatened with river blocks to paralyse shipments to Botnia and 'other secret actions to enhance the protest' (30/12/2007).

In December 2007, Cristina Kirchner was elected as the new president of Argentina, and she voiced that the dispute should be resolved in The Hague ICJ. This led to both governments agreeing on finding a diplomatic solution to the conflict. In early 2008, the protest and roadblocks continued on the border bridges but with less intensity. Despite the opposition, the CEAG divided internally into supporters of the roadblocks and those who claimed that the roadblocks should cease as its 'strategic value' was decreasing $(23 / 08 / 2008)$. Additionally, the roadblocks experienced lack of support on the 
Argentinean side of the River Uruguay, because the method was affecting the bilateral relationship with Uruguay. The government stated that the 'right to the protest has exceeded the limits of respect' and thus, the roadblocks had 'no legitimacy' (23/11/2008). In November 2008, the firm was operating at full capacity. In 2009, Botnia's operations in Uruguay were reassigned to the Finnish company UPM-Kymmene Corporation. Stakeholder influence during the solution seeking event are presented in Table 6.

Table 6 Stakeholder influence tactics utilised during the solution seeking

\begin{tabular}{|c|c|c|}
\hline Intended outcome & Mass participation & Elite participation \\
\hline \multirow[t]{2}{*}{ Material damage } & \multirow[t]{2}{*}{ (Not utilised) } & $\begin{array}{l}\text { - CEAG: Roadblocks against Botnia, } \\
\text { the Uruguayan Government, and the } \\
\text { Argentinean Government }\end{array}$ \\
\hline & & $\begin{array}{l}\text { - UG: Roadblock to support Botnia } \\
\text { and avoid conflicts when the firm } \\
\text { started to operate }\end{array}$ \\
\hline Material gain & (Not utilised) & $\begin{array}{l}\text { - UG: Supporting Botnia by building } \\
\text { a new harbour and giving the } \\
\text { authorisation to start to operate }\end{array}$ \\
\hline \multirow[t]{2}{*}{ Symbolic damage } & \multirow{2}{*}{$\begin{array}{l}\text { - CEAG: Demonstrations } \\
\text { against Botnia, the Uruguayan } \\
\text { Government, and the } \\
\text { Argentinean Government }\end{array}$} & $\begin{array}{l}\text { - CEAG: Opposition within the } \\
\text { organisation regarding the } \\
\text { effectiveness of the roadblocks }\end{array}$ \\
\hline & & $\begin{array}{l}\text { - AG: Opposing CEAG and its } \\
\text { roadblocks }\end{array}$ \\
\hline \multirow[t]{2}{*}{ Symbolic gain } & \multirow[t]{2}{*}{ (Not utilised) } & $\begin{array}{l}\text { - AG: Involvement of King of Spain } \\
\text { as mediator, meetings with } \\
\text { Uruguayan Government }\end{array}$ \\
\hline & & $\begin{array}{l}\text { - UG: Meetings with the Argentinean } \\
\text { Government }\end{array}$ \\
\hline
\end{tabular}

Source: Compiled by the authors

During the solution seeking stage, the governments organised joint meetings and negotiations to solve the conflict. This influence can be classified as symbolic gain as the aim was to create goodwill and agreement between the countries. The material gain tactic was used by the Uruguayan Government as it built a new harbour and granted authorisation for starting the operations of Botnia. The Argentinean Government continued to oppose the roadblocks. In this event, the mass participation tactic was utilised only by the CEAG through organising demonstrations.

\subsection{Summary of the stakeholder-firm and inter-stakeholder influences}

Regarding the stakeholder-firm influences, the Uruguayan Government collaborated with Botnia during the project using both material and symbolic gain influences. The material gain influence included provisioning the authorisation for the project and the construction of the ONTUR harbour at the end of the project. The symbolic gain influence was applied by offering continuous support to the firm.

The inter-stakeholder influence tactic most frequently utilised by the Uruguayan Government was the use of verbal accusations, which represented a symbolic damage influence as the main objective was to affect the Argentinean Government's reputation. 
This tactic was used throughout the megaproject. The symbolic gain tactic was utilised during the last event when the participants tried to find solutions to the conflict. During this stage, the governments organised joint meetings and negotiations. During the last events, the Uruguayan Government also utilised the material damage tactic through making official complaints to the Mercosur and by blocking the border bridges to oppose Argentina and the CEAG and to avoid conflicts.

The Argentinean Government sought to influence Botnia and the megaproject through other actors, most notably Uruguay. During the project, Argentina sought to exert material damage on Botnia by cancelling exports and by appealing to the World Bank to cancel the project's funding. During the events, Argentina mostly engaged in inter-stakeholder influences. Argentina used the material damage tactic only in the appeal to The Hague ICJ, while the material gain tactic was not utilised at all during the key events. Throughout the project, the Argentinean Government, similar to the Uruguayan Government, relied on symbolic damage in the form of verbal accusations. First, Argentina opposed Uruguay and, later on, also the CAEG as the roadblocks were deemed harmful for finding solutions to the conflict. Symbolic gain was used when Argentina showed support to the CEAG and when the two countries agreed to organise meetings and negotiations to solve the conflict.

The CEAG sought to influence the project by simultaneously utilising material and symbolic damage tactics. The roadblocks were intended to harm the construction projects, and the demonstrations were aimed to influence public opinion and to strengthen opposition for the project. The same tactics were utilised in the interstakeholder influences as well throughout the project. In the early stages of the project, the roadblocks and the demonstrations were intended for opposing Uruguay. During the last events of the project, the Argentinean Government was also opposed as CEAG complained about the government's passivity during the megaproject. In contrast to the governments relying only on elite participation, the CEAG also utilised mass participation by organising demonstrations.

Regarding stakeholder-firm influences, the citizens of Fray Bentos utilised two different tactics during the first key events of the project. First, the citizens organised and participated in demonstrations as a mass participation tactic to oppose the project, thus exerting symbolic damage. Later, the citizens' view on the project changed from opposition to support, and, accordingly, the influence evolved from symbolic damage to symbolic gain. Likewise, regarding the inter-stakeholder influences, the citizens utilised demonstrations first to oppose Uruguay and later to oppose the activities of the CEAG. In summary, this stakeholder group utilised only mass participation tactics.

\section{Discussion}

This study shows, first, that stakeholder influences are interdependent and non-exclusive and demonstrates how stakeholder influence evolves over time through the main events of a megaproject as the conflict and the project progressed. The stakeholder influence evolved during the main events of the megaproject in various ways. In the beginning, the stakeholders sought to influence others by exerting damage and gain logics, and, as the conflict evolved, material and symbolic damage tactics were used more than gain tactics. When the dispute evolved, elite participation was commonly utilised to exert symbolic damage in the form of involving external stakeholders. This focus on damage shows how 
stakeholders react in opposing each other when the project gets heated. However, gaining influence was again utilised during the solution seeking stage when the governments agreed to organise meetings and joint negotiations. At the final stage of the project, elite participation tactics were the most frequent influence for both positive and negative purposes. Also, tactics to exert symbolic and material gain emerged again due to the efforts to solve the conflict. Moreover, mass participation tactics were barely utilised during the last moments of the dispute.

Second, we argue that we need to study inter-stakeholder influence in addition to stakeholder-firm influence to fully understand how stakeholder influence emerges and evolves in megaprojects. We used the stakeholder-firm framework (den Hond and de Bakker, 2007) to analyse the inter-stakeholder influence and showed that stakeholder influence consists of the multiple and simultaneous interests that the focal firm must consider (Rowley, 1997; Zietsma and Winn, 2008). In the beginning of the project, both governments were prone to use elite participation tactics - that is, relying on a limited number of people participating in the activities (den Hond and de Bakker, 2007) to directly influence the firm and other stakeholders. Moreover, both governments first aimed to influence the focal firm directly, while later they utilised indirect influence in the form of involving new external stakeholders in the dispute. On the contrary, mass participation was used by the CEAG and the citizens of Fray Bentos to influence public opinion about the case. Mass participation is a more indirect way of influencing the focal firm or other stakeholders because it relies on the power of the masses.

Furthermore, most frequently, the stakeholders exerted a direct influence on other stakeholder groups and an indirect influence on the firm through other stakeholders. Regularly, the stakeholders provided or denied support to one actor with the objective of influencing another stakeholder. For example, the Argentinean Government supported the CEAG as a method to influence the Uruguayan Government and the project, exerting a logic of symbolic gain influence on the CEAG as a means to perform a logic of symbolic damage influence on the Uruguayan Government and Botnia. This demonstrates that stakeholder influences are not exclusive; rather, they are interdependent and can be applied simultaneously.

Finally, by analysing the inter-stakeholder influence, the study shed new light on the previous literature on secondary stakeholders and the ways their influence is understood in megaprojects (Di Maddaloni and Davis, 2017). Secondary stakeholders, such as NGOs and local communities, have been scarcely addressed in previous research. One possible reason is that secondary stakeholders are less powerful and less likely or able to directly influence the success of the project. However, secondary stakeholders may have considerable indirect influence, and, by analysing inter-stakeholder activities, their influence can be acknowledged and understood as part of the progress of a megaproject. The findings of this study suggest that secondary stakeholders may seek to influence public opinion and other stakeholders by mass participation tactics, such as demonstrations. They may also seek to ally with other stakeholders to increase their power and engage in radical tactics such as roadblocks.

As a managerial implication, the current study can help managers understand how stakeholders can seek to influence a megaproject through stakeholder-firm and inter-stakeholder influences. By understanding stakeholders' actions, managers can engage more constructively with these groups and anticipate their actions to avoid disputes. 
The main limitation of the current study is that the research data were obtained from only one newspaper; additional sources might have provided a more extensive description of the influences. Moreover, because the current study analysed only one case study, the generalisability of the results is therefore limited. Thus, we encourage more research on this topic utilising various sources of data. Further research on inter-stakeholder influences is particularly recommended.

\section{Conclusions}

The purpose of this study was to examine stakeholder influence in megaprojects. The theoretical framework was based on stakeholder theory, with a focus on stakeholder influences in international megaprojects. The empirical analysis focused on a controversial pulp mill project in Uruguay. Qualitative content analysis was used to analyse 96 newspaper articles from 2005 to 2009. The findings presented the main events of the megaproject and how the stakeholder-firm and inter-stakeholder influences emerged and evolved during the project. The study showed that stakeholder influences evolve over time and are interdependent and non-exclusive. By examining the inter-stakeholder influence in addition to the stakeholder-firm influence, the study extended the earlier stakeholder-firm classification and discussed also the secondary stakeholder influences. For managers, the study emphasises the importance of understanding how stakeholders can be influenced by or, alternatively, exert influence in megaprojects.

\section{Acknowledgements}

The authors gratefully acknowledge the financial support from the Foundation for Economic Education, the University of Tampere Foundation, the Academy of Finland (Decision number 298663) and the Strategic Research Council at the Academy of Finland (Decision numbers 320194 and 320206).

\section{References}

Aaltonen, K. (2013) 'The establishment of legitimacy: the case of international projects', International Journal of Managing Projects in Business, Vol. 6, No. 1, pp.13-35.

Aaltonen, K. and Kujala, J. (2010) 'A project lifecycle perspective on stakeholder influence strategies in global projects', Scandinavian Journal of Management, Vol. 26, No. 4, pp.381-397.

Aaltonen, K., Kujala, J., Lehtonen, P. and Ruuska, I. (2010) 'A stakeholder network perspective on unexpected events and their management in international projects', International Journal of Managing Projects in Business, Vol. 3, No. 4, pp.564-588.

Bunn, M.D., Savage, G.T. and Holloway, B.B. (2002) 'Stakeholder analysis for multi-sector innovations', Journal of Business \& Industrial Marketing, Vol. 17, Nos. 2/3, pp.181-203.

Clarkson, M.E. (1995) 'A stakeholder framework for analyzing and evaluating corporate social performance', Academy of Management Review, Vol. 20, No. 1, pp.92-117.

de Bakker, F.G. and den Hond, F. (2008a) 'Introducing the politics of stakeholder influence: a review essay', Business \& Society, Vol. 47, No. 1, pp.8-20. 
de Bakker, F.G. and den Hond, F. (2008b) 'Activists' influence tactics and corporate policies', Business Communication Quarterly, Vol. 71, No. 1, pp. 107-111.

den Hond, F. and de Bakker, F.G. (2007) 'Ideologically motivated activism: how activist groups influence corporate social change activities', Academy of Management Review, Vol. 32, No. 3, pp.901-924.

Di Maddaloni, F. and Davis, K. (2017) 'The influence of local community stakeholders in megaprojects: rethinking their inclusiveness to improve project performance', International Journal of Project Management, Vol. 35, No. 8, pp.1537-1556.

Elo, S. and Kyngäs, H. (2008) 'The qualitative content analysis process', Journal of Advanced Nursing, Vol. 62, No. 1, pp.107-115.

Eskerod, P., Huemann, M. and Savage, G. (2015) 'Project stakeholder management - past and present', Project Management Journal, Vol. 46, No. 6, pp.6-14.

Flyvbjerg, B. (2014) 'What you should know about megaprojects and why: an overview', Project Management Journal, Vol. 45, No. 2, pp.6-19.

Freeman, R.E. (Ed.) (1984) Strategic Management: A Stakeholder Approach, Pitman, Boston.

Frooman, J. (1999) 'Stakeholder influence strategies', Academy of Management Review, Vol. 24, No. 2, pp.191-205.

Frooman, J. and Murrell, A.J. (2005) 'Stakeholder influence strategies: the roles of structural and demographic determinants', Business \& Society, Vol. 44, No. 1, pp.3-31.

Heikkinen, A., Kujala, J. and Lehtimäki, H. (2013) 'Managing stakeholder dialogue: the case of Botnia in Uruguay', South Asian Journal of Business and Management Cases, Vol. 2, No. 1, pp.25-37.

Hendry, J.R. (2005) 'Stakeholder influence strategies: an empirical exploration', Journal of Business Ethics, Vol. 61, No. 1, pp.79-99.

Hsieh, H.F. and Shannon, S.E. (2005) 'Three approaches to qualitative content analysis', Qualitative Health Research, Vol. 15, No. 9, pp.1277-1288.

Joutsenvirta, M. and Vaara, E. (2009) 'Discursive (de)legitimation of a contested Finnish greenfield investment project in Latin America', Scandinavian Journal of Management, Vol. 25, No. 1, pp.85-96.

King, B. (2008) 'A social movement perspective of stakeholder collective action and influence', Business \& Society, Vol. 47, No. 1, pp.21-49.

Kolk, A. and Fortanier, F. (2013) 'Internationalization and environmental disclosure: the role of home and host institutions', Multinational Business Review, Vol. 21, No. 1, pp.87-114.

Kujala, J., Heikkinen, A. and Lehtimäki, H. (2012) 'Understanding the nature of stakeholder relationships: an empirical examination of a conflict situation', Journal of Business Ethics, Vol. 109, No. 1, pp.53-65.

Kujala, J., Toikka, T. and Heikkinen, A. (2009) 'Communicating corporate responsibility through media', Progress in Industrial Ecology, An International Journal, Vol. 6, No. 4, pp.404-420.

Laasonen, S. (2010) 'The role of stakeholder dialogue: NGOs and foreign direct investments', Corporate Governance, Vol. 10, No. 4, pp.527-537.

Laplume, A.O., Sonpar, K. and Litz, R.A. (2008) 'Stakeholder theory: reviewing a theory that moves us', Journal of Management, Vol. 34, No. 6, pp.1152-1189.

Lehtimäki, H. and Kujala, J. (2017) 'Framing dynamically changing firm-stakeholder relationships in an international dispute over a foreign investment: a discursive analysis approach', Business \& Society, Vol. 56, No. 3, pp.487-523.

Lehtimäki, H., Kujala, J. and Heikkinen, A. (2011) 'Corporate responsibility in communication: empirical analysis of press releases in a conflict', Business Communication Quarterly, Vol. 74, No. 4, pp.432-449.

Moffat, K. and Zhang, A. (2014) 'The paths to social license to operate: an integrative model explaining community acceptance of mining', Resources Policy, Vol. 39, No. 1, pp.61-70. 
Mok, K.Y., Shen, G.Q. and Yang, J. (2015) 'Stakeholder management studies in mega construction projects: a review and future directions', International Journal of Project Management, Vol. 33, No. 2, pp.446-457.

Morrill, C., Zald, M.N. and Rao, H. (2003) 'Covert political conflict in organizations: challenges from below', Annual Review of Sociology, Vol. 29, No. 1, pp.391-415.

Neville, B.A. and Menguc, B. (2006) 'Stakeholder multiplicity: toward an understanding of the interactions between stakeholders', Journal of Business Ethics, Vol. 6, No. 4, pp.377-391.

Pacheco, D.F. and Dean, T.J. (2015) 'Firm responses to social movement pressures: a competitive dynamics perspective', Strategic Management Journal, Vol. 36, No. 7, pp.1093-1104.

Rowley, T.J. (1997) 'Moving beyond dyadic ties: a network theory of stakeholder influences', Academy of Management Review, Vol. 22, No. 4, pp.887-910.

Rowley, T.J. and Moldoveanu, M. (2003) 'When will stakeholder groups act? An interest-and identity-based model of stakeholder group mobilization', Academy of Management Review, Vol. 28, No. 2, pp.204-219.

Skippari, M. and Pajunen, K. (2010) 'MNE-NGO-Host government relationships in the escalation of an FDI conflict', Business \& Society, Vol. 49, No. 4, pp.619-651.

Viveros, H. (2017) 'Unpacking stakeholder mechanisms to influence corporate social responsibility in the mining sector', Resources Policy, Vol. 51, pp.1-12.

Yang, J., Shen, G.Q., Ho, M., Drew, D.S. and Xue, X. (2011) 'Stakeholder management in construction: an empirical study to address research gaps in previous studies', International Journal of Project Management, Vol. 29, No. 7, pp.900-910.

Zietsma, C. and Winn, M.I. (2008) 'Building chains and directing flows: strategies and tactics of mutual influence in stakeholder conflicts', Business \& Society, Vol. 47, No. 1, pp.68-101.

\section{Appendix}

Table A1 List of articles included in the final sample

\begin{tabular}{lcl}
\hline $\begin{array}{l}\text { Article } \\
\text { number }\end{array}$ & $\begin{array}{c}\text { Publication } \\
\text { date }\end{array}$ & \multicolumn{1}{c}{ Translated title (original title) } \\
\hline 1 & $29 / 04 / 2005$ & $\begin{array}{l}\text { Argentineans and Uruguayans, together against the construction of } \\
\text { the pulp mills. [Argentinos y uruguayos, unidos en un abrazo contra } \\
\text { la instalación de papeleras.] }\end{array}$ \\
2 & $15 / 05 / 2005$ & $\begin{array}{l}\text { Uruguay will not go backwards on the construction of the pulp } \\
\text { mills. [Uruguay no dará marcha atrás contra la instalación de } \\
\text { plantas celulósicas.] } \\
\text { There will be no funding for the Pulp mills in Uruguay. [No habrá } \\
\text { dinero para las papeleras sobre el Uruguay.] }\end{array}$ \\
4 & $15 / 07 / 2005$ & $\begin{array}{l}\text { Diplomatic tension over the pulp mills in Uruguay. [Tensión } \\
\text { diplomática por las papeleras sobre el Uruguay.] } \\
\text { The government asked Uruguay to stop the construction of the pulp } \\
\text { mills. [El Gobierno pidió que Uruguay frene la construcción de las } \\
\text { papeleras.] } \\
\text { The World Bank is going to examine the pulp mills in the River } \\
\text { Uruguay. [El Banco Mundial va a inspeccionar las papeleras en el } \\
\text { río Uruguay.] }\end{array}$ \\
\hline
\end{tabular}

Source: Compiled by the authors 
Table A1 List of articles included in the final sample (continued)

\begin{tabular}{|c|c|c|}
\hline $\begin{array}{l}\text { Article } \\
\text { number }\end{array}$ & $\begin{array}{l}\text { Publication } \\
\text { date }\end{array}$ & Translated title (original title) \\
\hline 7 & 09/10/2005 & $\begin{array}{l}\text { The possible establishment of another pulp mill in Uruguay is } \\
\text { announced. [Anuncian la posible instalación de otra papelera en } \\
\text { Uruguay.] }\end{array}$ \\
\hline 8 & $19 / 10 / 2005$ & $\begin{array}{l}\text { Tabaré Vázquez will set the cornerstone of one of the pulp mills. } \\
\text { [Tabaré Vázquez pondrá la piedra fundamental de una de las } \\
\text { papeleras.] }\end{array}$ \\
\hline 9 & $11 / 11 / 2005$ & $\begin{array}{l}\text { A delivery to one of the pulp mills is blocked. [Frenan un envío a } \\
\text { una de las papeleras.] }\end{array}$ \\
\hline 10 & $27 / 12 / 2005$ & $\begin{array}{l}\text { Pulp mills: the government insists on the suspension of the } \\
\text { construction work. [Papeleras: el Gobierno insiste con la suspension } \\
\text { de las obras.] }\end{array}$ \\
\hline 11 & $30 / 12 / 2005$ & $\begin{array}{l}\text { Roadblocks for the pulp mills: delays up to } 3 \text { hours to cross to } \\
\text { Uruguay. [Cortes por las papeleras: demoras de hasta } 3 \text { horas para } \\
\text { cruzar a Uruguay.] }\end{array}$ \\
\hline 12 & $14 / 01 / 2006$ & $\begin{array}{l}\text { Chaos in the international bridges in the first touristic term of the } \\
\text { summer. [Caos en los puentes internacionales en el primer recambio } \\
\text { turístico del verano.] }\end{array}$ \\
\hline 13 & $17 / 01 / 2006$ & $\begin{array}{l}\text { Diplomatic tension: after the meeting of the council of ministers. } \\
\text { [Tensión diplomática: tras la reunión del consejo de ministros.] }\end{array}$ \\
\hline 14 & $01 / 02 / 2006$ & $\begin{array}{l}\text { Conflict in Uruguay: another chapter in the dispute about the pulp } \\
\text { mills in Fray Bentos. [Conflicto en Uruguay: otro capítulo de la } \\
\text { disputa por las plantas en Fray Bentos.] }\end{array}$ \\
\hline 15 & $26 / 02 / 2006$ & $\begin{array}{l}\text { The conflict with Uruguay: update on the pulp mills in Fray Bentos. } \\
\text { [El conflicto con Uruguay: la situación de las plantas de celulosa en } \\
\text { Fray Bentos.] }\end{array}$ \\
\hline 16 & $16 / 03 / 2006$ & $\begin{array}{l}\text { The conflict with Uruguay: contacts in Montevideo and the Finnish } \\
\text { pulp mill. [El conflicto con Uruguay: contactos en Montevideo y la } \\
\text { papelera finlandesa.] }\end{array}$ \\
\hline 17 & $27 / 03 / 2006$ & $\begin{array}{l}\text { The conflict with Uruguay: before the presidential summit. [El } \\
\text { conflicto con Uruguay: antes de la cumbre presidencial.] }\end{array}$ \\
\hline 18 & 09/04/2006 & $\begin{array}{l}\text { The conflict with Uruguay: exclusive interview with the chancellor } \\
\text { Jorge Taiana. [El conflicto con Uruguay: entrevista exclusiva con el } \\
\text { canciller Jorge Taiana.] }\end{array}$ \\
\hline 19 & $21 / 04 / 2006$ & $\begin{array}{l}\text { The conflict with Uruguay: characteristics of one of the pulp mills } \\
\text { in Fray Bentos. [El conflicto con Uruguay: características de una de } \\
\text { las plantas en Fray Bentos.] }\end{array}$ \\
\hline 20 & $22 / 04 / 2006$ & $\begin{array}{l}\text { The conflict with Uruguay: warning about the impact on future } \\
\text { investments in the region. [El conflicto con Uruguay: advierten } \\
\text { sobre el impacto en futuras inversiones en la región.] }\end{array}$ \\
\hline 21 & $05 / 05 / 2006$ & $\begin{array}{l}\text { The conflict with Uruguay: presentations about the pulp mills in the } \\
\text { International Court of Justice. [El conflicto con Uruguay: } \\
\text { presentaciones por las papeleras ante la Corte Internacional de } \\
\text { Justicia.] }\end{array}$ \\
\hline 22 & $21 / 05 / 2006$ & $\begin{array}{l}\text { Interview with Erkki Varis, president of the pulp mill Botnia. } \\
\text { [Entrevista a Erkki Varis, presidente de la papelera Botnia.] }\end{array}$ \\
\hline
\end{tabular}

Source: Compiled by the authors 
Table A1 List of articles included in the final sample (continued)

\begin{tabular}{|c|c|c|}
\hline $\begin{array}{l}\text { Article } \\
\text { number }\end{array}$ & $\begin{array}{l}\text { Publication } \\
\text { date }\end{array}$ & Translated title (original title) \\
\hline 23 & 09/06/2006 & $\begin{array}{l}\text { The conflict with Uruguay: the lawsuit against Uruguay in The } \\
\text { Hague International Court of Justice. [El conflicto con Uruguay: la } \\
\text { demanda contra Uruguay en la Corte Internacional de Justicia de La } \\
\text { Haya.] }\end{array}$ \\
\hline 24 & $11 / 06 / 2006$ & $\begin{array}{l}\text { The conflict with Uruguay: the lawsuit to stop the construction of } \\
\text { the pulp mills. [El conflicto con Uruguay: la demanda para detener } \\
\text { la construcción de las papeleras.] }\end{array}$ \\
\hline 25 & 07/07/2006 & $\begin{array}{l}\text { The conflict with Uruguay: first phase in the trial at the } \\
\text { International Court of Justice. [El conflicto con Uruguay: primera } \\
\text { etapa del juicio ante la Corte Internacional de Justicia.] }\end{array}$ \\
\hline 26 & $23 / 07 / 2006$ & $\begin{array}{l}\text { The conflict with Uruguay: after the setback at The Hague } \\
\text { International Court. [El conflicto con Uruguay: después del revés en } \\
\text { el Tribunal Internacional de La Haya.] }\end{array}$ \\
\hline 27 & $22 / 09 / 2006$ & $\begin{array}{l}\text { Clarín had anticipated that it was leaving from Fray Bentos. [Clarín } \\
\text { había anticipado que se iba de Fray Bentos.] }\end{array}$ \\
\hline 28 & $24 / 09 / 2006$ & The conflict about the pulp mills. [El conflicto con las pasteras.] \\
\hline 29 & $17 / 10 / 2006$ & $\begin{array}{l}\text { A river block is proposed to block the Harbour of Botnia. [Proponen } \\
\text { hacer un corte fluvial para bloquear el Puerto de Botnia.] }\end{array}$ \\
\hline 30 & $18 / 10 / 2006$ & $\begin{array}{l}\text { Strong endorsement for the establishment of the pulp mills. [Fuerte } \\
\text { aval a la instalación de las pasteras.] }\end{array}$ \\
\hline 31 & $15 / 11 / 2006$ & $\begin{array}{l}\text { Key funding for the Finnish pulp mill in Uruguay. [Financiamiento } \\
\text { clave para la planta de la pastera finlandesa en Uruguay.] }\end{array}$ \\
\hline 32 & $18 / 11 / 2006$ & $\begin{array}{l}\text { The conflict with Uruguay about the pulp mills: Kirchner had sent a } \\
\text { letter to the World Bank asking for its delay. [El conflicto con } \\
\text { Uruguay por las papeleras: Kirchner había enviado una carta al } \\
\text { Banco Mundial pidiendo su postergación.] }\end{array}$ \\
\hline 33 & $10 / 12 / 2006$ & $\begin{array}{l}\text { The conflict with Uruguay: Clarín had access to the preview of the } \\
\text { presentation to be given this Monday } 18 \text { at the Court of Justice. [El } \\
\text { conflicto con Uruguay: Clarín accedió al adelanto de la } \\
\text { presentación que hará el lunes } 18 \text { ante la Corte de Justicia.] }\end{array}$ \\
\hline 34 & $18 / 12 / 2006$ & $\begin{array}{l}\text { The conflict with Uruguay: a hearing starts today at The Hague } \\
\text { about the roadblocks. [El conflicto con Uruguay: Hoy comienza una } \\
\text { audiencia en La Haya por los cortes de ruta.] }\end{array}$ \\
\hline 35 & 07/01/2007 & $\begin{array}{l}\text { The conflict with Uruguay: project to build an island to cover the } \\
\text { chimney of Fray Bentos. [El conflicto con Uruguay: el proyecto de } \\
\text { levantar una isla para que no se vea la chimenea de Fray Bentos.] }\end{array}$ \\
\hline 36 & $23 / 01 / 2007$ & $\begin{array}{l}\text { The conflict with Uruguay: over } 4 \text { years of dispute about the } \\
\text { Uruguayan pulp mills. [El conflicto con Uruguay: más de } 4 \text { años de } \\
\text { puja por las papeleras uruguayas.] }\end{array}$ \\
\hline 37 & $02 / 02 / 2007$ & $\begin{array}{l}\text { The conflict with Uruguay: statements from Finland in an } \\
\text { Argentinean radio. [El conflicto con Uruguay: declaraciones desde } \\
\text { Finlandia a una radio argentina.] }\end{array}$ \\
\hline 38 & $05 / 02 / 2007$ & $\begin{array}{l}\text { Businessmen talk for the first time since the conflict with Uruguay } \\
\text { started. [Por primera vez desde que estalló el conflicto con Uruguay } \\
\text { hablan los hombres de negocios.] }\end{array}$ \\
\hline
\end{tabular}


Table A1 List of articles included in the final sample (continued)

\begin{tabular}{|c|c|c|}
\hline $\begin{array}{l}\text { Article } \\
\text { number }\end{array}$ & $\begin{array}{l}\text { Publication } \\
\text { date }\end{array}$ & Translated title (original title) \\
\hline 39 & $23 / 03 / 2007$ & $\begin{array}{l}\text { External front: visit of the Uruguayan president to Fray Bentos. [El } \\
\text { frente externo: visita del presidente uruguayo a Fray Bentos.] }\end{array}$ \\
\hline 40 & $30 / 03 / 2007$ & $\begin{array}{l}\text { Clarín visited the facilities of the Finnish company in Fray Bentos. } \\
\text { [Clarín recorrió las instalaciones de la empresa finlandesa en Fray } \\
\text { Bentos.] }\end{array}$ \\
\hline 41 & $11 / 04 / 2007$ & $\begin{array}{l}\text { An initiative that the government will present next week to the } \\
\text { round table discussions in Spain. [Una iniciativa que el gobierno } \\
\text { llevará la semana que viene a la mesa de dialogo en España.] }\end{array}$ \\
\hline 42 & $17 / 04 / 2007$ & $\begin{array}{l}\text { The conflict with Uruguay: interview with Erkki Varis, president of } \\
\text { the Finnish company. [El conflicto con Uruguay: entrevista a Erkki } \\
\text { Varis, presidente de la empresa finlandesa.] }\end{array}$ \\
\hline 43 & $15 / 05 / 2007$ & $\begin{array}{l}\text { After having an interview with the chancellor Jorge Taiana. [Luego } \\
\text { de entrevistarse con el canciller Jorge Taiana.] }\end{array}$ \\
\hline 44 & $31 / 05 / 2007$ & $\begin{array}{l}\text { There is no hurry in Argentina to force a definition before October. } \\
\text { [No hay apuro argentino por forzar una definición antes de octubre.] }\end{array}$ \\
\hline 45 & 19/06/2007 & Environmentalists. [Ambientalistas.] \\
\hline 46 & 19/07/2007 & $\begin{array}{l}\text { He assured it at The Hague Court of Justice, as an answer to the } \\
\text { Argentinean complaint. [Lo aseguró ante el Tribunal de La Haya, } \\
\text { como respuesta al reclamo argentino.] }\end{array}$ \\
\hline 47 & $31 / 07 / 2007$ & $\begin{array}{l}\text { Good work of Spain in the conflict between Argentina and } \\
\text { Uruguay. [Buenos oficios de España en el conflicto argentino - } \\
\text { uruguayo.] }\end{array}$ \\
\hline 48 & $21 / 08 / 2007$ & $\begin{array}{l}\text { A key route for the economy of Mercosur was blocked. } \\
\text { [Interrupción de una vía clave para la economía del Mercosur.] }\end{array}$ \\
\hline 49 & $30 / 08 / 2007$ & $\begin{array}{l}\text { The conflict about the pulp mills: despite the energetic proposal of } \\
\text { the Argentinean chancellery. [El conflicto por las papeleras: a pesar } \\
\text { del enérgico planteo de la cancillería argentina.] }\end{array}$ \\
\hline 50 & 02/09/2007 & $\begin{array}{l}\text { The conflict with Uruguay: tension over the complaint of Entre Ríos } \\
\text { in Fray Bentos. [El conflicto con Uruguay: tensión por el reclamo } \\
\text { de entrerrianos en Fray Bentos.] }\end{array}$ \\
\hline 51 & $03 / 09 / 2007$ & $\begin{array}{l}\text { The conflict with Uruguay: over } 850 \text { people crossed from } \\
\text { Gualeguaychú to Fray Bentos to ask for the relocation of the pulp } \\
\text { mill. [El conflicto con Uruguay: unas } 850 \text { personas cruzaron de } \\
\text { Gualeguaychú a Fray Bentos para pedir la relocalización de la } \\
\text { planta.] }\end{array}$ \\
\hline 52 & $26 / 09 / 2007$ & $\begin{array}{l}\text { Highlight: the international issue that worry the most to Cristina } \\
\text { Kirchner. [En foco: el tema internacional que más preocupa a } \\
\text { Cristina Kirchner.] }\end{array}$ \\
\hline 53 & $03 / 10 / 2007$ & $\begin{array}{l}\text { A new solution to the conflict between Argentina and Uruguay? } \\
\text { [¿Una nueva salida para el conflicto entre la Argentina y Uruguay?] }\end{array}$ \\
\hline 54 & $04 / 10 / 2007$ & $\begin{array}{l}\text { The pulp mill will then start its production. [La pastera pondrá en } \\
\text { marcha entonces su producción.] }\end{array}$ \\
\hline 55 & $10 / 11 / 2007 a$ & $\begin{array}{l}\text { Meeting before the summit starts. [Reunión antes del inicio de la } \\
\text { cumbre.] }\end{array}$ \\
\hline
\end{tabular}

Source: Compiled by the authors 
Table A1 List of articles included in the final sample (continued)

\begin{tabular}{|c|c|c|}
\hline $\begin{array}{l}\text { Article } \\
\text { number }\end{array}$ & $\begin{array}{c}\text { Publication } \\
\text { date }\end{array}$ & Translated title (original title) \\
\hline 56 & $10 / 11 / 2007 b$ & $\begin{array}{l}\text { The crisis with Uruguay aggravates: borders closed and Botnia } \\
\text { started to operate. [Se agravó la crisis con Uruguay: cerró frontera y } \\
\text { arrancó Botnia.] }\end{array}$ \\
\hline 57 & $25 / 11 / 2007$ & $\begin{array}{l}\text { The Argentinean government showed its "concern and disgust". [El } \\
\text { gobierno argentino transmitió su "preocupación y desagrado".] }\end{array}$ \\
\hline 58 & $26 / 11 / 2007$ & $\begin{array}{l}\text { Tension increases over the bilateral conflict. [Crece la tensión en el } \\
\text { conflicto bilateral.] }\end{array}$ \\
\hline 59 & $02 / 12 / 2007$ & Sugar or saccharin? [¿Azúcar o sacarina?] \\
\hline 60 & $30 / 12 / 2007$ & The conflict over Botnia. [El conflicto por Botnia.] \\
\hline 61 & $23 / 01 / 2008$ & $\begin{array}{l}\text { Botnia: "Argentina missed the chance to earn lots of money with } \\
\text { us". [Botnia: "Argentina perdió de ganar muchísimo dinero con } \\
\text { nosotros".] }\end{array}$ \\
\hline 62 & $28 / 01 / 2008$ & $\begin{array}{l}\text { The conflict with Uruguay over the pulp mill Botnia. [El conflicto } \\
\text { con Uruguay por la pastera Botnia.] }\end{array}$ \\
\hline 63 & $02 / 02 / 2008$ & $\begin{array}{l}\text { When accepting, Cristina Kirchner promised to respect the } \\
\text { resolution of the International Court of Justice. [Al asumir, Cristina } \\
\text { Kirchner prometió respetar lo que resuelva el Tribunal } \\
\text { Internacional.] }\end{array}$ \\
\hline 64 & $13 / 02 / 2008$ & $\begin{array}{l}\text { Buenos Aires and Montevideo will wait for the resolution of The } \\
\text { Hague Court of Justice. [Buenos Aires y Montevideo esperarán el } \\
\text { fallo de la Corte de La Haya.] }\end{array}$ \\
\hline 65 & $01 / 03 / 2008$ & $\begin{array}{l}\text { Facing the boycott of the Assembly members of Gualeguaychú. } \\
\text { [Frente al boicot de los asambleístas de Gualeguaychú.] }\end{array}$ \\
\hline 66 & $22 / 03 / 2008$ & $\begin{array}{l}\text { The Argentinean Court expects to listen this week to the managers } \\
\text { of Botnia. [La Justicia argentina espera escuchar esta semana a los } \\
\text { directivos de Botnia.] }\end{array}$ \\
\hline 67 & $24 / 04 / 2008$ & Moving forward. [En marcha.] \\
\hline 68 & $27 / 04 / 2008$ & $\begin{array}{l}\text { Gualeguaychú: a crowd demonstrated against the pulp mill. } \\
\text { [Gualeguaychú: una multitud marchó contra la papelera.] }\end{array}$ \\
\hline 69 & $15 / 05 / 2008$ & $\begin{array}{l}\text { Finland plans more investments in Uruguay. [Finlandia proyecta } \\
\text { más inversiones en Uruguay.] }\end{array}$ \\
\hline 70 & $23 / 08 / 2008$ & $\begin{array}{l}\text { Gualeguaychú: a judge gave the order to let one Argentinean cross } \\
\text { the bridge. [Gualeguaychú: una jueza ordenó que dejen cruzar el } \\
\text { puente a un argentino.] }\end{array}$ \\
\hline 71 & $21 / 09 / 2008$ & $\begin{array}{l}\text { The interest in observing the Finnish pulp mill from the city of } \\
\text { Entre Ríos. [El interés por observar a la pastera finlandesa desde la } \\
\text { ciudad entrerriana.] }\end{array}$ \\
\hline 72 & 28/09/2008 & $\begin{array}{l}\text { Cristina might be trying to stop the roadblock in Gualeguaychú. } \\
\text { [Cristina estaría intentando levantar el corte de ruta en } \\
\text { Gualeguaychú.] }\end{array}$ \\
\hline 73 & 03/10/2008 & The conflict over the pulp mills. [El conflicto por las papeleras.] \\
\hline 74 & $19 / 10 / 2008$ & $\begin{array}{l}\text { The conflict with Uruguay over the Finnish pulp mill. [El conflicto } \\
\text { con Uruguay por la papelera finlandesa.] }\end{array}$ \\
\hline
\end{tabular}

Source: Compiled by the authors 
Table A1 List of articles included in the final sample (continued)

\begin{tabular}{|c|c|c|}
\hline $\begin{array}{l}\text { Article } \\
\text { number }\end{array}$ & $\begin{array}{l}\text { Publication } \\
\text { date }\end{array}$ & Translated title (original title) \\
\hline 75 & $10 / 11 / 2008$ & $\begin{array}{l}\text { Botnia is already producing as much cellulose as } 30 \text { Argentinean } \\
\text { pulp mills together. [Botnia ya produce tanta celulosa como } 30 \\
\text { papeleras argentinas.] }\end{array}$ \\
\hline 76 & 23/11/2008 & $\begin{array}{l}\text { The roadblock in the international bridge created a conflict with } \\
\text { Uruguay. [El bloqueo del puente internacional produjo un conflicto } \\
\text { con Uruguay.] }\end{array}$ \\
\hline 77 & $15 / 12 / 2008 \mathrm{a}$ & $\begin{array}{l}\text { Meeting of Mercosur, Unasur, Calc and the Group Río. [Reunión } \\
\text { del Mercosur, Unasur, Calc y el Grupo Río.] }\end{array}$ \\
\hline 78 & $15 / 12 / 2008 b$ & $\begin{array}{l}\text { He implied that "low-interest" pickets were not allowed. [Dio a } \\
\text { entender que no se permiten piquetes de "baja adhesión".] }\end{array}$ \\
\hline 79 & 02/01/2009 & $\begin{array}{l}\text { Pulp mill: Urribarri will greet the Assembly members, but the } \\
\text { roadblock continues. [Papelera: Urribarri recibirá a los } \\
\text { asambleístas, pero sigue el corte.] }\end{array}$ \\
\hline 80 & 08/01/2009 & $\begin{array}{l}\text { Uruguay asked the government for "facts" regarding its rejection of } \\
\text { the roadblocks. [Uruguay pidió al Gobierno que "traduzca en } \\
\text { hechos" su rechazo a los cortes.] }\end{array}$ \\
\hline 81 & 29/01/2009 & $\begin{array}{l}\text { The conflict over the pulp mill Botnia. [El conflicto por la papelera } \\
\text { Botnia.] }\end{array}$ \\
\hline 82 & 05/02/2009 & $\begin{array}{l}\text { The conflict over the Finnish pulp mill. [El conflicto por la pastera } \\
\text { finesa.] }\end{array}$ \\
\hline 83 & 06/02/2009 & $\begin{array}{l}\text { There were suspicions of pollution due to the presence of the pulp } \\
\text { mill Botnia. [Había sospechas de contaminación por la presencia de } \\
\text { la pastera Botnia.] }\end{array}$ \\
\hline 84 & 08/03/2009 & $\begin{array}{l}\text { Sunday topic, first highlight: the other side of the conflict over the } \\
\text { pulp mill. [Tema de domingo, primera nota: la otra cara del } \\
\text { conflicto por la pastera.] }\end{array}$ \\
\hline 85 & 23/03/2009 & $\begin{array}{l}\text { The conflict with Uruguay over the Finnish pulp mill. [El conflicto } \\
\text { con Uruguay por la pastera finesa.] }\end{array}$ \\
\hline 86 & 27/04/2009 & $\begin{array}{l}\text { First fatal accident in the setting of the protest in Entre Ríos. } \\
\text { [Primer accidente mortal en el escenario de la protesta entrerriana.] }\end{array}$ \\
\hline 87 & $10 / 05 / 2009$ & $\begin{array}{l}\text { Jussi Pakkasvirta political scientist and Finnish historian. [Jussi } \\
\text { Pakkasvirta politólogo e historiador finlandés.] }\end{array}$ \\
\hline 88 & 19/06/2009 & Decision of the environmentalists. [Decisión de los ambientalistas.] \\
\hline 89 & $16 / 09 / 2009$ & $\begin{array}{l}\text { Second day of presentations at The Hague Court of Justice. } \\
\text { [Segunda jornada de presentaciones en el Tribunal de La Haya.] }\end{array}$ \\
\hline 90 & 22/09/2009 & $\begin{array}{l}\text { Presentation at The Hague Court of Justice. [Presentación en el } \\
\text { Tribunal de La Haya.] }\end{array}$ \\
\hline 91 & 20/10/2009 & $\begin{array}{l}\text { New controversy concerning the roadblock in the route } 136 \text {, while } \\
\text { the elections are approaching on Sunday. [Nueva polémica por el } \\
\text { corte de la ruta 136, de cara a las elecciones del domingo.] }\end{array}$ \\
\hline 92 & $31 / 10 / 2009$ & $\begin{array}{l}\text { The chancellery rejected the allegations and ensured that the pulp } \\
\text { mill is already polluting. [La cancillería rechazó la acusación y } \\
\text { asegura que la pastera ya contamina.] }\end{array}$ \\
\hline
\end{tabular}

Source: Compiled by the authors 
Table A1 List of articles included in the final sample (continued)

\begin{tabular}{lcl}
\hline $\begin{array}{l}\text { Article } \\
\text { number }\end{array}$ & $\begin{array}{c}\text { Publication } \\
\text { date }\end{array}$ & \multicolumn{1}{c}{ Translated title (original title) } \\
\hline 93 & $19 / 11 / 2009$ & $\begin{array}{l}\text { Bilateral conflict: Botnia concludes its first export to Argentina. } \\
\text { [Conflicto bilateral: Botnia cierra su primera exportación a } \\
\text { Argentina.] }\end{array}$ \\
94 & $27 / 11 / 2009$ & $\begin{array}{l}\text { Statement of the ruling party candidate to the weekly newspaper } \\
\text { "Búsqueda" of Montevideo. [Declaraciones del candidato oficialista } \\
\text { al semanario "Búsqueda" de Montevideo.] }\end{array}$ \\
95 & $\begin{array}{l}\text { Seeking to defuse the bilateral relations. [Buscan distender las } \\
\text { relaciones bilaterales.] } \\
\text { Botnia: minimizing the frictions with Tabaré about Botnia is now } \\
\text { sought. [Botnia: ahora se busca minimizar los roces con Tabaré por } \\
\text { Botnia.] }\end{array}$ \\
\hline
\end{tabular}

Source: Compiled by the authors 